\title{
Investigating the Situation of Lacquered Wire Kavir Yazd Company in Lifecycle and the Fit between Marketing Strategy and Marketing Mix
}

\author{
Aliakbar Beygiyazdi ${ }^{1}$, Shahnaz Nayebzadeh ${ }^{2 *}$, Abolfazl Davoodi Roknabadi ${ }^{3}$ \\ ${ }^{1}$ Department of Management, Yazd Branch, Islamic Azad University, Yazd, Iran \\ ${ }^{2}$ Associate Professor, Department of Management, Yazd Branch, Islamic Azad University, Yazd, Iran \\ ${ }^{3}$ Department of Design and Clothing, Yazd Branch, Islamic Azad University, Yazd, Iran
}

Keywords:

Strategic Reference Points, Life Cycle, Marketing Strategy, Marketing Mix, Fuzzy Analytic Hierarchy Process.

Received

17 November 2017

Received in revised form

22 October 2018

Accepted

24 October 2018

Correspondence:

Snayebzadeh@iauyazd.ac.ir
AbSTRACT

A strategy is the basic pattern of current and planned objectives, operation and allocation of resources, an organization's interactions with the markets, competitors, and other environmental factors. The main focus of marketing strategy is to allocate and coordinate with marketing activities and resources, and to provide operational objectives in terms of a market - specific product. The strategy can determine success in the world of today mega competitive in the life cycle of the organization if properly allocate organization's resources and marketing mix also fit in with this strategy. The aim of this study was to examine the life cycle of Kavir Lacquered Wire of Yazd Company and its status in the company's life cycle and to review the fit between company's marketing strategy and marketing. The judgmental method sampling among managers and experts was applied and the descriptive research which employed questionnaire and survey methods was used to collect the data. Descriptive statistics showed that this company is in the growth stage of its life cycle and the company's strategic reference points shows that the attack or siege were the main reason of choosing marketing strategy. Data analysis techniques using fuzzy AHP also revealed that the company marketing mix and marketing strategy had only the promotion fit. According to the wire Kavir Yazd Company approach in the context of intelligence capabilities and scientific management; investigating the company's position in the life cycle and also company's strategy and marketing mix will eventually improve manager insight in marketing management. 


\section{Introduction}

The speed of change and evolution in the present arena is so fast that understanding its path is not easily possible; however, the managers of organizations should lead and guide themselves and their relevant organization in the maze of time according to this change and evolution. Nowadays, companies in order to develop products with higher performance are increasingly under their customers' pressure. In this respect the successful companies by applying their key resources, capabilities, and competences in the strategic process framework try to create a stable and unique competitive situation in the market (Jafarnejad \& Mokhtarzadeh, 2007). Regarding the vitality of effectiveness of marketing process, and the efficiency of production process to achieve customers' proper and desired performance and company's success in the competitive conditions that governing market, the companies should achieve a balance between production efficiency and marketing effectiveness by creating an integration between the activities of two major domains of production and marketing to meet customers' demands and requirements and also to increase their sale and profitability (Bateson \& Hoffman,1999). With regard to the present conditions, the companies and institutions should take long term policies to face with problems and do activities along with the competitors, and every company should compile a perfect and comprehensive plan with regard to the vision, mission, goals, conditions and domestic facilities, and foreign environmental opportunities and threats. Marketing is in connection with the process of exchanging between purchasers and sellers, and it is an endeavor that adapts supply with demand. The subject of this exchange might be products, services, technologies, business systems, people, information, concepts or thoughts (MasoumzadehZavareh \& Nasehifar, 2010).

It is the responsibility of managers and strategists of service and production units that by equipping their researcher forces, start organizational operations targeting towards far and close markets and predicting sale level, and certain market share for future periods, and this issue is only possible by the aid of scientific methods and approaches of marketing (Talebzadeh, 2010).

Industrial marketing is the process of discovering and translating industrial customers' demands and their needs and requirements to special products and services to effective relationship of the methods of distribution, pricing, after sale services, and convincing more and more customers to use products and services continuously (Ghasemi, Taghavi, \& Fani, 2006). Marketing experts have expressed various goals for compiling marketing strategy, that in all of them company's marketing performance improvement is the main axis. This point has special importance in Lacquered Wire Kavir Yazd Company, that is the place of performing present research, because by growing trend of global competition and the entrance of international competitors to the industries of country, the attention of selected industry of this research should also be attracted more than ever towards the strategic decisions issue that has a vital and determining role in competition status and companies' survival. In the modern literature, the management of each one of the duties of managers such as planning, organizing, controlling, etc. is a manifestation of decision making. In this regard, decision making about marketing mix elements and also determining relative priority of each one shapes the basic foundation of marketing system, because in addition to satisfying target 
market needs, the marketing and organizational goals should also be considered in it. Thus, in this research the following objectives have been proposed:

1) Investigating the situation of Lacquered Wire Kavir Yazd Company in lifecycle with regard to the strategic reference points.

2) Investigating marketing strategy of Lacquered Wire Kavir Yazd Company in life stage.

3) Investigating the fit between marketing strategy and marketing mix of Lacquered Wire Kavir Yazd Company by using Fuzzy Analytic Hierarchy Process technique.

To investigate the objectives proposed in this research, the following questions will be answered:

Question 1: What is the situation of Lacquered Wire Kavir Yazd Company in lifecycle with regard to the strategic reference points?

Question 2: What is the marketing strategy of Lacquered Wire Kavir Yazd Company in its life stage?

Question 3: Is there a fit between marketing strategy and marketing mix of Lacquered Wire Kavir Yazd Company by using Fuzzy Analytic Hierarchy Process technique?

\section{Strategy and Strategic Management}

Every organization usually faces with various models or ways for its activities and attempts to select the most appropriate one for leading operations. These models and methods are called strategic options that the managers and planers should analyze and evaluate and ultimately choose one of them as the main strategy of organization. Chandler (1962) suggested that strategy is to determine the basic and long term goals of an organization and selecting measures and allocating necessary resources for achieving these goals. Strategic management is a process that needs many mutual relationships, and the existence of effective coordination between organizational management and the managers of functional and business levels in performing it, is obligatory.

\section{Strategic Reference Points}

Reference point is a place or point that all measurements and selections are assessed in comparing with it. The organization chooses the strategic reference points to achieve strategic coordination or to perform appropriate measures and operations. In other words, the strategic reference points are the points for coordination, and if all the elements and systems of organization coordinate themselves with them, a comprehensive coordination is created (Arabi \& Rezvani, 2007). Two strategic reference points of marketing are "the consideration ratio of organization to the current or new markets" and "the ratio of competition". Table 1 shows these two reference points.

Table 1

Features of Strategic Management Decisions in Various Levels (Arabi \& Rezvani, 2007)

\begin{tabular}{|c|c|c|c|}
\hline \multicolumn{2}{|c|}{$\begin{array}{c}\text { Strategic Reference Points of } \\
\text { Marketing }\end{array}$} & \multirow{2}{*}{$\begin{array}{l}\text { Descriptions } \\
\begin{array}{l}\text { High number of competitors, low control on factors (flexibility), } \\
\text { distinguished products. }\end{array}\end{array}$} & \multirow{2}{*}{$\begin{array}{c}\begin{array}{c}\text { Lifecycle Stages of } \\
\text { Corresponding Product }\end{array} \\
\text { Growth and Maturity }\end{array}$} \\
\hline First SRP & High & & \\
\hline ra & Low & Low number of competitors, strict control on factors, standard pro & Emergence and Decline \\
\hline \multirow{2}{*}{$\begin{array}{l}\text { Second SRP- focus } \\
\text { axis, inside or outside } \\
\text { current markets }\end{array}$} & Domestic & $\begin{array}{l}\text { Maintaining current market, maintaining the share of current market } \\
\text { mentions the efficiency of organization. }\end{array}$ & ecline \\
\hline & Foreign & $\begin{array}{l}\text { Obtaining new market, increasing market share refers to the } \\
\text { effectiveness of organization. }\end{array}$ & Emergence and Growth \\
\hline
\end{tabular}




\section{Marketing Strategy}

Marketing strategy is a tool whereby the goals are obtained. These strategies are related to the question that how the goals can be actualized. The success of marketing plan depends on the marketing strategy efficiency. Actually marketing strategy includes different variables that the company can control or adapt itself with uncontrollable variables to achieve its goals appropriately. The group of variables that are controllable are related to the internal authorities and facilities of company, and the other group that are not controllable are environmental variables including demand, competition forces, distribution structure, marketing laws, and non-marketing costs. The controllable variables of marketing strategy include product, price, place, distribution, staff, assets, physical facilities and process (Aliahmadi, Fathollah, \& Tajoldin, 2003).

\section{Life Stages of Organization}

The stages of lifetime have specific order and natural path, and the structure of organization, leadership method, and the administrative system of organizations follow a relatively predictable model that exists in the lifetime stages (Shafiei, 2012). The companies have lifecycle and are evolved through passing a sequence of stages and continuous and certain changes during the time (Rezaie \& Samani, 2014), in a way that the previous researchers have stated four major stages for describing company's lifecycle.

\section{Start-up or Emerging Stage}

In the emerging stage, the assets ratio (company's size) is usually located at low level, the cash flows obtained from operational activities and profitability is low, and the companies need high liquidity for financing and realizing growth opportunities. The dividend ratio in these companies is usually $10 \%$ maximum, and the internal rate of return compared with the rate of established financing is trivial; in other word, the equation is IRR $\leq \mathrm{K}$ (Adizes, 1989).

\section{Growth Stage}

In the growth stage, the company's size is more than the size of companies in the emerging stage, the sale and incomes ratio compared with the emerging stage is more too. The financial resources are also more in invested generating assets, and the company has more flexibility in liquidity indicators. The dividend interest ratio in this range of companies is usually at vibration between $10 \%$ and $50 \%$. The internal rate of return is often more than the rate of financing cost; in other word, the equation of IRR $>K$ is established (Adizes, 1989).

\section{Maturity Stage}

In the maturity stage, the companies experience stable and balanced sale, the need to cash is fulfilled through internal sources in most cases. The assets size of these companies is proportionately more than the size of companies in the growth stage, and this proportion is usually at vibration between $50 \%$ and $100 \%$. Due to the liquidity abundance and reduction of reliance on the policy of financing from outside, the internal rate of return in these companies is equal or more than the financing rate. In other words, the equation of IRR $\geq \mathrm{K}$ is established (Adizes, 1989). 


\section{Decline or Stagnation Stage}

With the arrival of the business unit into the decline stage, business risk also increases (Osta \& Gheytasi, 2012). In the decline stage, the growth opportunities are generally very trivial. The indicators of profitability and liquidity, and fulfilling commitments have declining trend and the company has been surrounded in a very hard competitive conditions, while the financing cost from foreign resources is high in a way that in most cases the internal rate of return is lower than the financing rate; In other word, the equation of IRR $<\mathrm{K}$ is established (Adizes, 1989).

\section{Marketing Mix}

The main philosophy of marketing management is based on four factors known as marketing mix (product, price, place, and promotion), and the strategic setting of marketing mix is appropriately regarded as one of the most pivotal success secrets of leading and prospective companies (Gheytarani, 2011). Marketing mix (product, price, distribution, and promotion) is among the important categories in decision makings and the evaluations related to the marketing of an enterprise, because marketing mix or marketing strategy is a combination of necessary elements for planning and implementing the whole marketing operations (Ketabi, Ansari, \& NaseriTaheri, 2005). Marketing mix is a set of controllable marketing variables that the company combines them with each other to acquire its expected reaction in target markets (Katler \& Armstrong, 2004). In other words, the combination of marketing mix is a program that attracts marketers' attention to itself (Goharian, 2010).

\section{Locating Pricing Approaches and Strategies in Product Lifecycle Based on the Strategic Reference Points of Marketing}

Based on the viewpoint of Walker et al., the product lifecycle model is a framework that shows the occurrence of opportunities and threats in the market and industry, whereby the companies can predict the change in the goal of product strategic market, change in its strategy, and change in the company's marketing plan better. Two main variables for specifying product lifecycle stages are: "competition ratio" (number of competitors), and "attention to the current or new market". By using these two strategic reference points, the stages of product lifecycle can be located in a matrix. Figure 1 shows the results of Arabi and Rezvani's (2007) research in this regard.

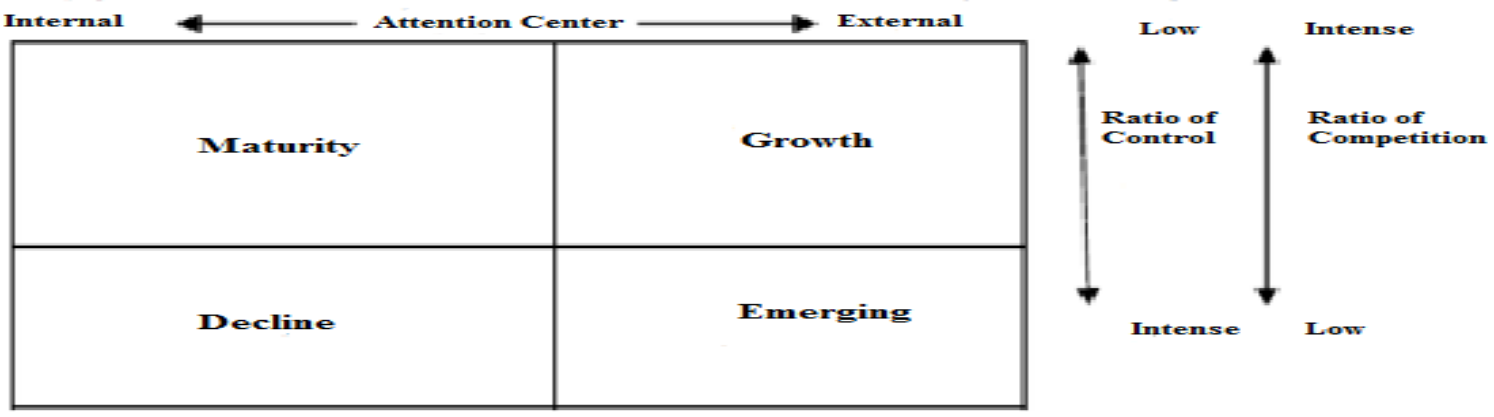

Figure 1. Locating product lifecycle stages in the matrix of strategic reference points (Arabi \& Rezvani, 2007) 


\section{A Review on Research History}

Anthony and Ramesh (1992) conducted a research entitled "Investigating the relationship between accounting performance and stock market price: testing lifecycle hypothesis". They investigated the relationship between performance evaluation criteria and the stock market price in various stages of business unit lifecycle and concluded that the reaction of stock market to performance criteria is a function of the stages of business unit lifecycle in a way that the ratio of relatedness of the criteria of sale growth and investment expenses from the emerging stage to decline stage has a downward trend. The results of Yoo, Donthu, and Lee's (2000) research, in investigating the value of brand from the customer's viewpoint in different cultures and about various products, has indicated that the brand value level based on the consumer's viewpoint is positively related to the consumer's understanding of the quality and brand, loyalty to the brand, and awareness of it, and the quality and reminders of brand by influencing loyalty to the brand impacts on the brand equity. Among the marketing mix, price, store image, and the distribution intensity had positive impact on the perceived quality of product. In contrary, sale promotion showed a negative impact (Yu et al., 2000).

Jenkins, Kane, and Velury (2004) investigated the impact of company's lifecycle in relatedness of profit components value. They assumed that business units in various stages of lifecycle have taken different strategic measures. The results of this research showed the relatedness of profit components value through emphasizing on profitability in the final stages of lifecycle, instead of emphasizing on the growth in the initial stages of lifecycle. Villarejo-Ramos and Sanchez-Franco (2005) in investigating the relationship between some of the marketing mix elements and the brand value about a class of durable products that have been based on brand value theory of Aker (1991), concluded that there is a positive relationship between the ratio of performed advertisements, and three dimensions of brand value that are perceived quality, awareness of brand, and notion of brand. The promotion of price had negative impact on brand; moreover, no positive relationship was found between the awareness of brand and notion about the brand (Villarejo-Ramos \& Sanchez-Franco, 2005).

In a research, Aharony, Falk, and Yehuda (2006) have compared the description ability of criteria based on cash flows and the criteria based on the accruals in explaining business units in various stages of lifecycle. The results indicated that the description ability of criteria based on the cash flows has been more in the growth stage; while the description ability of the criteria based on accruals is more in the stages of maturity and decline. Kallunki and Silvola (2008) in an article entitled "Investigating the impact of organizational lifecycle stage on using Activity-Based Costing" examined the ratio of using Activity-Based Costing system in various lifecycle of company, and concluded that the ratio of using Activity-Based Costing system in the stages of start-up and maturity compared with the growth stage, is more. Gohar (2010) investigated the lifecycle of business unit and the type of dividend payment. In this research, three different groups of business units have been considered that distribute cash including stock repurchase, cash dividend, and a combination of stock repurchase. This study shows that the lifecycle of business unit is among the most important reasons for choosing dividend payment methods. 
In their study, Kim and Hyum (2010) investigated the relationship between marketing mix, that includes distribution channel performance, pricing based on value, and after sale services, and the company's image on three dimensions of brand equity including brand awareness and reminder, perceived quality, and loyalty to the brand. The results showed that marketing mix performance has positive relationship with brand equity, and the company's image adjusts the impact of marketing mix on all three components of brand equity. Bulan and Yan (2010) in an article entitled as "Maturity of companies and hierarchy theory" by classifying the life of companies into two stages of growth and maturity, investigated the hierarchy theory. They identified the impact of size and maturity. The results revealed that the hierarchy theory describes better the financing decisions of greater and mature companies compared with the smaller and in the growth stage companies. Huang and Sarigöllü (2012) investigated the relationship of awareness of brand equity and marketing mix. They found that there is not significant relationship between awareness of brand and sale, market share, and brand equity. The hypothesis of the impact of advertisements on the awareness of brand has not been confirmed either. The analyses in this research indicated that there is a positive relationship between distribution and awareness of brand, and between price and advertisements.

\section{Method}

The method of present research is "applied" type, because the chosen company and other active companies in this industry can use its expected results and ultimately causes promotion of managers' insight in the marketing management area, and since data collection is at one period, the research is among the cross-sectional researches type. It is among the nonexperimental researches type in respect of the possibility of controlling variables and it is located in the classification of non-experimental researches of descriptive researches type.

\section{Participants}

The managers and experts of Lacquered Wire Kavir Yazd Company composed the statistical population of present research. The sampling was performed by judgmental method and the number of sample was 10 people.

\section{Procedures}

In this research the data collection was performed by field method. In this part, the data was collected by using questionnaire tool including six months' period from March to August 2016. In the present study, two questionnaires were used that included a Five-point Likerttype questionnaire related to the lifecycle based on the strategic reference points and also marketing strategy, and a Nine-point Likert-type questionnaire was the fit of marketing strategy with marketing mix as well. The validity of mentioned questionnaires that performs paired comparison of the indicators and components according to the model is largely dependent on the reliability of hierarchy process technique. Moreover, to acquire more confidence about the validity of criteria and questionnaire, the viewpoints and consultations of advisor and consultant professors were used. In order to assure the expressiveness of 
questionnaire framework, the experts' suggestions were also used to make final changes on the questionnaire.

\section{Data Analysis}

The descriptive statistics was exploited for the analysis of experts' viewpoints, and investigating the status of company in its lifecycle on the basis of strategic reference points, and also recognizing the marketing strategy of company. The weight of marketing mix indicators of company was investigated by using fuzzy analytic hierarchy process technique and the fit between chosen marketing strategy and marketing mix was specified.

\section{Results}

\section{First Stage: Lifetime of Organization}

Considering the following matrix, based on the strategic reference points, the lifetime of organization is identifiable in four stages, and the managers and experts of company responded the questionnaires and the results have been obtained as in Figure 2 below.

Table 2

Strategic Reference Points in Determining the Lifetime of Companies (Walker et al., 2003)

\begin{tabular}{|c|c|c|c|c|c|c|c|c|c|c|}
\hline Effectiveness & Efficiency & & & & & & & & & \\
\hline $\begin{array}{l}\text { Market } \\
\text { share } \\
\text { increase } \\
\text { Heterogeneou } \\
\text { market }\end{array}$ & $\begin{array}{c}\text { Maintaining } \\
\text { current market } \\
\text { share } \\
\text { Homogenous } \\
\text { market }\end{array}$ & & & & & & & & & \\
\hline $\begin{array}{l}\text { Acquiring } \\
\text { new market }\end{array}$ & $\begin{array}{l}\text { Maintaining } \\
\text { current market }\end{array}$ & & & & & & & & & \\
\hline $\begin{array}{l}\text { Emphasis } \\
\text { on } \\
\text { profitability } \\
\text { in future } \\
\text { time }\end{array}$ & $\begin{array}{l}\text { Emphasis on } \\
\text { profitability in } \\
\text { present time }\end{array}$ & & & & & & & & & \\
\hline $\begin{array}{c}\uparrow \\
\text { Gowth } \\
\text { Stage }\end{array}$ & $\begin{array}{c}\uparrow \\
\begin{array}{c}\text { Maturity } \\
\text { Stage }\end{array} \\
\longrightarrow\end{array}$ & $\begin{array}{c}\text { Predictab } \\
\text { ility of } \\
\text { low } \\
\text { market } \\
\text { decline }\end{array}$ & $\begin{array}{l}\text { Low } \\
\text { control } \\
\text { ratio }\end{array}$ & $\begin{array}{c}\text { High } \\
1 \text { competencies } \\
\text { of competitors }\end{array}$ & $\begin{array}{l}\text { Accessibility } \\
\text { of } \\
\text { competitors } \\
\text { to high } \\
\text { resources }\end{array}$ & $\begin{array}{l}\text { Low } \\
\text { flexi } \\
\text { bility }\end{array}$ & $\begin{array}{l}\text { Distinguis } \\
\text { hed } \\
\text { products }\end{array}$ & $\begin{array}{c}\text { High } \\
\text { number of } \\
\text { competitors }\end{array}$ & $\begin{array}{c}\text { High } \\
\text { power of } \\
\text { competitors }\end{array}$ & $\begin{array}{l}\text { Competitive } \\
\text { advantage of } \\
\text { company } \\
\text { compared } \\
\text { with low } \\
\text { competitors }\end{array}$ \\
\hline$\underset{\substack{\text { Emergence } \\
\text { Stage }}}{\longrightarrow}$ & $\begin{array}{c}\underset{\text { Decline }}{\text { Stage }} \\
\longrightarrow\end{array}$ & $\begin{array}{l}\text { Predicta } \\
\text { bility of } \\
\text { high } \\
\text { market } \\
\text { decline }\end{array}$ & $\begin{array}{l}\text { High } \\
\text { control } \\
\text { ratio }\end{array}$ & $\begin{array}{c}\text { Low } \\
\text { competencies } \\
\text { of competitors }\end{array}$ & $\begin{array}{l}\text { Accessibili } \\
\text { ty of } \\
\text { competitor } \\
\text { s to low } \\
\text { resources }\end{array}$ & $\begin{array}{l}\text { High } \\
\text { flexi } \\
\text { bility }\end{array}$ & $\begin{array}{l}\text { Standard } \\
\text { products }\end{array}$ & $\begin{array}{c}\text { Low } \\
\text { number of } \\
\text { competitors }\end{array}$ & $\begin{array}{c}\text { Low } \\
\text { power of } \\
\text { competitors }\end{array}$ & $\begin{array}{c}\text { Competitive } \\
\text { advantage of } \\
\text { company } \\
\text { compared } \\
\text { with high } \\
\text { competitors }\end{array}$ \\
\hline
\end{tabular}

As presented in Table 2, based on the strategic reference points with regard to the results obtained from related questionnaire and experts' viewpoints responding to them, the Lacquered Wire Kavir Yazd Company can be considered at the growth stage of its lifetime.

\section{Second Stage: Company's Marketing Strategy}

In this stage, the experts were asked to answer about the company's strategic approach concerning marketing in four lifetimes of company, i.e., the company's most appropriate 
strategic approach in the marketing domain in four periods. The results showed that with the company's current conditions in the second stage of life that is the company's growth stage, the respondents to the questions have agreed with choosing their marketing strategy. The strategies of company's life stages in five types based on the strategic reference points are introduced in the following matrix. Considering these results, it can be said that the company has chosen attack from surrounding or blockade marketing strategy according to the respondents' viewpoints.

Table 3

Marketing Strategies in Company's Growth Stage with Regard to the Strategic Reference Points (Walker et al., 2003)

\begin{tabular}{lllll}
\hline $\begin{array}{l}\text { Acquiring new } \\
\text { market }\end{array}$ & $\begin{array}{l}\text { Maintaining current } \\
\text { market }\end{array}$ & & & \\
\hline $\begin{array}{c}\text { Attack from } \\
\text { surrounding, } \\
\text { Blockade }\end{array}$ & Low control ratio & Low flexibility & $\begin{array}{c}\text { High number of } \\
\text { competitors }\end{array}$ & $\begin{array}{c}\text { High power of } \\
\text { competitors }\end{array}$ \\
& High control ratio & High flexibility & $\begin{array}{c}\text { Low number of } \\
\text { competitors }\end{array}$ & $\begin{array}{c}\text { Low power of } \\
\text { competitors }\end{array}$
\end{tabular}

Third Stage: Company's Marketing Mix

A Review on Research Operational Steps

This research has been performed by doing 4 steps as follows:

- First Step: Identifying Components and Indicators and Drawing Hierarchy Structure of Research Conceptual Model

In this stage, research literature (articles, books, and related studies) was investigated, and four major components of marketing mix were specified, and five indicators were determined for each one. Four major components were in the research literature and common resources. The selective indicators were also chosen from the indicators that had the highest repetition in research literature and can be referred in line with the companies' selected marketing strategy (Figure 5). 


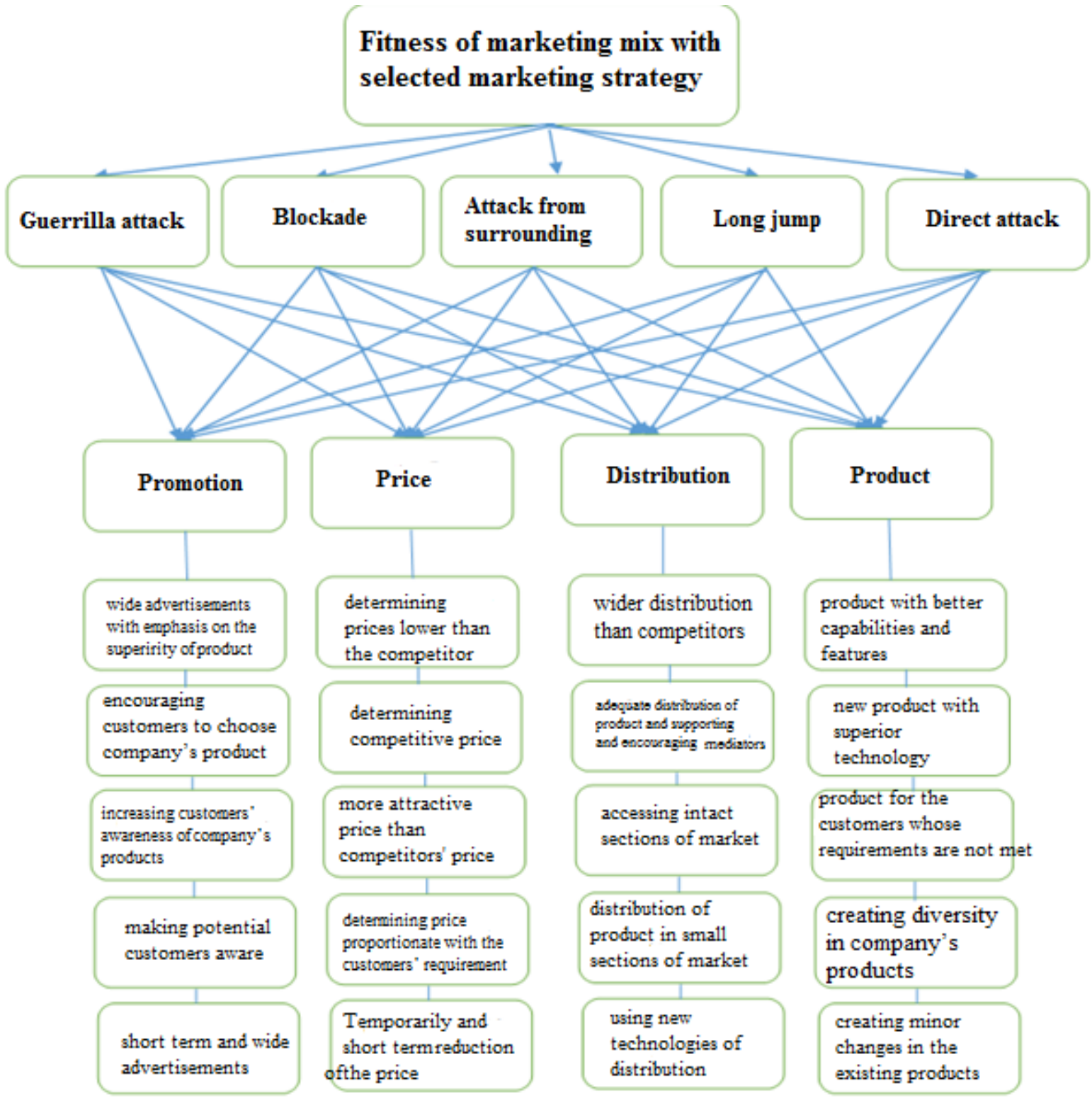

Figure 2. Diagram of the fitness of marketing mix with selected marketing strategy

\section{- Second and Third Steps}

The calculations and results of second and third steps are as follows: The experts of this research by using paired comparisons matrix and based on the scores from 1 to 9 specified the importance ratio of each one of the components, and then the geometric mean of these comparisons have been calculated. For confidence and trusting the rationality of performed comparisons, the adjustment rate was used; and since this rate was less than 0.1 , hence, the performed comparisons can logically be trusted. Then the weight of each one of the components was calculated by using normalization. This process was performed for all components and indicators.

\section{Indicators of Product Components}

According to the matrix obtained from group-paired comparisons of the indicators of product components, the indicator of "creating minor changes in the existing products of company" 
had the highest priority and the indicator of "producing product with better capabilities and features than competitor's products" had the lowest priority. For confidence and trusting the rationality of performed comparisons, the adjustment rate was used; and since this rate was less than 0.1 , hence, the performed comparisons can logically be trusted.

\section{Indicators of Pricing Component}

According to the matrix obtained from group-paired comparisons of the indicators of pricing components, the indicator of "determining competitive price" had the highest priority and the indicator of "determining prices lower than the competitor (at the same time reducing the costs of company)" had the lowest priority. For confidence and trusting the rationality of performed comparisons, the adjustment rate was used; and since this rate was less than 0.1 , hence, the performed comparisons can logically be trusted.

\section{Indicators of Product Distribution Component}

According to the matrix obtained from group-paired comparisons of the indicators of product distribution components, the indicator of "adequate distribution of product and supporting and encouraging distribution mediators" had the highest priority and the indicator of "using new technologies of distribution such as internet selling" had the lowest priority. For confidence and trusting the rationality of performed comparisons, the adjustment rate was used; and since this rate was less than 0.1 , hence, the performed comparisons can logically be trusted.

\section{Indicators of Advertisement Component}

According to the matrix obtained from group-paired comparisons of the indicators of advertisements component, the indicator of "trying to increase customers' awareness of company's products" had the highest priority and the indicator of "wide and short term advertisements and using price discount policies for encouraging customers" had the lowest priority. For confidence and trusting the rationality of performed comparisons, the adjustment rate was used; and since this rate was less than 0.1 , hence, the performed comparisons can logically be trusted.

\section{- Fourth Step}

Having performed calculations related to the first, second, and third steps, in this stage by multiplying the weight of each one of the components in the relative weight of each one of the indicators, the final weights of indicators have been calculated, and the indicators have been prioritized. As indicated in Table 4, totally the indicators of "adequate distribution of product and supporting and encouraging distribution mediators", "trying to increase customers' awareness of the company's products", and "encouraging customers to choose company's product instead of choosing competitors' products" have allocated the highest priorities to themselves; and the indicators of "determining prices lower than the competitor (at the same time reducing the costs of company)", "producing product with better capabilities and features than competitor's products", and "temporarily and short term reducing the price" have allocated the lowest priorities to themselves. 
Table 4

Calculation of Final Weight and Ranking Each One of the Indicators

\begin{tabular}{|c|c|c|c|c|c|c|}
\hline Components & $\begin{array}{l}\text { Weight of } \\
\text { Components }\end{array}$ & Indic & Name of Indicator & $\begin{array}{l}\text { Relative } \\
\text { Weight }\end{array}$ & $\begin{array}{c}\text { Final } \\
\text { Weight }\end{array}$ & Rank \\
\hline \multirow{5}{*}{ Product } & \multirow{5}{*}{0.198} & 1 & $\begin{array}{l}\text { Producing product with better capabilities and features than } \\
\text { competitor's products }\end{array}$ & 0.068 & 0.013 & 19 \\
\hline & & 2 & $\begin{array}{l}\text { Producing new product with superior technology that has more } \\
\text { benefits for the customers }\end{array}$ & 0.219 & 0.043 & 9 \\
\hline & & 3 & $\begin{array}{l}\text { Producing product with more attractive features for the customers } \\
\text { whose requirements are not met }\end{array}$ & 0.184 & 0.037 & 11 \\
\hline & & 4 & $\begin{array}{l}\text { Creating diversity in company's products based on the requirement } \\
\text { of various sections of market }\end{array}$ & 0.150 & 0.030 & 15 \\
\hline & & 5 & Creating minor changes in the company's existing products & 0.379 & 0.075 & 5 \\
\hline \multirow{5}{*}{ Pricing } & \multirow{5}{*}{0.102} & 1 & $\begin{array}{l}\text { Determining prices lower than the competitor (at the same time } \\
\text { reducing the costs of company) }\end{array}$ & 0.068 & 0.007 & 20 \\
\hline & & 2 & Determining competitive price & 0.342 & 0.035 & 12 \\
\hline & & 3 & $\begin{array}{l}\text { Choosing more attractive price than competitor's price for the } \\
\text { customer }\end{array}$ & 0.172 & 0.018 & 17 \\
\hline & & 4 & $\begin{array}{l}\text { Determining price proportionate with the customers' requirement in } \\
\text { various sections of market }\end{array}$ & 0.276 & 0.028 & 16 \\
\hline & & 5 & Temporarily and short term reduction of the price & 0.142 & 0.014 & 18 \\
\hline \multirow{5}{*}{$\begin{array}{l}\text { Product } \\
\text { Distribution }\end{array}$} & \multirow{5}{*}{0.381} & 1 & Wider distribution than competitors & 0.163 & 0.062 & 6 \\
\hline & & 2 & $\begin{array}{l}\text { Adequate distribution of product and supporting and encouraging } \\
\text { distribution mediators }\end{array}$ & 0.356 & 0.136 & 1 \\
\hline & & 3 & Creating distribution channels for accessing intact sections of market & 0.233 & 0.089 & 4 \\
\hline & & 4 & $\begin{array}{l}\text { Trying to distribute product in small sections of market with specific } \\
\text { requirements }\end{array}$ & 0.149 & 0.057 & 7 \\
\hline & & 5 & Using new technologies of distribution such as internet selling & 0.099 & 0.038 & 10 \\
\hline \multirow{5}{*}{ Promotion } & \multirow{5}{*}{0.309} & 1 & $\begin{array}{l}\text { Wide advertisements with emphasis on the superiority of company's } \\
\text { product than competitors' }\end{array}$ & 0.146 & 0.045 & 8 \\
\hline & & 2 & $\begin{array}{l}\text { Encouraging customers to choose company's product instead of } \\
\text { choosing competitors' products }\end{array}$ & 0.286 & 0.088 & 3 \\
\hline & & 3 & Trying to increase customers' awareness of company's products & 0.359 & 0.111 & 2 \\
\hline & & 4 & $\begin{array}{l}\text { Wide advertisements with the aim of making potential customers } \\
\text { aware of the company's products }\end{array}$ & 0.109 & 0.034 & 13 \\
\hline & & 5 & $\begin{array}{l}\text { Wide and short term advertisements and using price discount policies } \\
\text { for encouraging customers }\end{array}$ & 0.101 & 0.031 & 14 \\
\hline
\end{tabular}

Table 4 reveals that "creating minor changes in the company's existing products" has been the managers' preference in the product domain, "determining competitive price" has been the managers' preference in the pricing domain, "adequate distribution of product and supporting and encouraging distribution mediators" has been the managers' preference in the distribution domain, and also 'trying to increase customers' awareness of company's products" has been the managers' preference in the promotion domain.

\section{Discussion and Conclusion}

Nowadays, competitiveness is considered to be as an essential approach to achieve profitability and sustainable development of active companies in B2B industries. Competitiveness is a quality realized via market governance and the formation of activities based on relative and competitive advantages. With a higher level of competitiveness, businesses gain more benefits. For gaining competitive advantage, companies should follow a strategic approach instead of a limited and technical view. The strategic reference points or the main determinants of competition and industry have a considerable impact on this strategic insight. These strategic reference points consist of concepts and variables such as the product homogeneity and the number and strength of competitors and define the position of companies in their life cycles. Managers can adopt different strategies for their companies in dealing with market in each stage of their business lifecycle. Various task strategies of each 
of these strategic reference points can be used as guides; and marketing strategies are responsive and innovative. If these strategies correspond well with the strengths and weaknesses of the company and also with the external environment full of threats and opportunities, they can help companies gain competitive advantage .

\section{Investigating the Fit of Marketing Mix with Company's Chosen Marketing Strategy}

Table 5

Strategy of Marketing Mix Factors for the Specific Growth Stage of the Following Company

\begin{tabular}{|c|c|c|c|c|c|}
\hline Strategy & Direct Attack & Long Jump & $\begin{array}{l}\text { Attack from } \\
\text { Surrounding }\end{array}$ & Blockade & Guerrilla Attack \\
\hline Product & $\begin{array}{l}\text { Producing and } \\
\text { supplying products with } \\
\text { batter capabilities and } \\
\text { appearance feature than } \\
\text { competitor's product }\end{array}$ & $\begin{array}{l}\text { Producing a new } \\
\text { generation of } \\
\text { products based on } \\
\text { different technology } \\
\text { that has better } \\
\text { performance or more } \\
\text { benefits for } \\
\text { customers of mass } \\
\text { market }\end{array}$ & $\begin{array}{l}\text { Producing } \\
\text { distinguished product } \\
\text { or product family } \\
\text { with more attractive } \\
\text { features for the } \\
\text { customers whose } \\
\text { requirements are not } \\
\text { met }\end{array}$ & $\begin{array}{l}\text { Increasing the } \\
\text { product diversity } \\
\text { or family with } \\
\text { numerous brands } \\
\text { for smaller } \\
\text { regional or applied } \\
\text { parts }\end{array}$ & $\begin{array}{l}\text { Not changing or } \\
\text { minor changes in } \\
\text { the product }\end{array}$ \\
\hline Price & $\begin{array}{l}\text { Prices lower than target } \\
\text { competitor (reducing } \\
\text { operational costs along } \\
\text { with it) }\end{array}$ & $\underline{\text { Competitive prices }}$ & $\begin{array}{l}\text { Attractive and unique } \\
\text { price }\end{array}$ & $\begin{array}{l}\text { Price appropriate } \\
\text { with unique } \\
\text { requirements of } \\
\text { smaller regional or } \\
\text { applied parts }\end{array}$ & $\begin{array}{l}\text { Short term price } \\
\text { reduction }\end{array}$ \\
\hline Distribution & $\begin{array}{l}\text { Designing and } \\
\text { exploiting the } \\
\text { scheduling systems of } \\
\text { production, controlling } \\
\text { inventory and better } \\
\text { logistics to minimize } \\
\text { delivering time and } \\
\text { reducing the times that } \\
\text { the required product of } \\
\text { customer that is not } \\
\text { available in the stores or } \\
\text { store of their inventory. } \\
\text { Spending more costs } \\
\text { than competitor to } \\
\text { distribute the product of } \\
\text { company wider in better } \\
\text { shelves of stores, } \\
\text { More sale or better } \\
\text { trained employees }\end{array}$ & $\begin{array}{l}\text { Adequate } \\
\text { distribution of } \\
\text { product through } \\
\text { business } \\
\text { contributions and } \\
\text { seller/mediator } \\
\text { programs }\end{array}$ & $\begin{array}{l}\text { Designing and } \\
\text { exploiting the } \\
\text { scheduling systems of } \\
\text { production, } \\
\text { controlling inventory } \\
\text { and better logistics to } \\
\text { minimize delivering } \\
\text { time and reducing the } \\
\text { times that the required } \\
\text { product of customer } \\
\text { that is not available in } \\
\text { the stores or store of } \\
\text { their inventory. } \\
\text { Creating distribution } \\
\text { channels for accessing } \\
\text { the intact sections of } \\
\text { market }\end{array}$ & $\begin{array}{l}\text { Designing and } \\
\text { exploiting the } \\
\text { scheduling systems } \\
\text { of production, } \\
\text { controlling } \\
\text { inventory and } \\
\text { better logistics to } \\
\text { minimize } \\
\text { delivering time } \\
\text { and reducing the } \\
\text { times that the } \\
\text { required product of } \\
\text { customer that is } \\
\text { not available in the } \\
\text { stores or store of } \\
\text { their inventory } \\
\text { particularly for } \\
\text { small applied and } \\
\text { regional parts }\end{array}$ & $\begin{array}{l}\text { Internet operations } \\
\text { or direct post with } \\
\text { accurate targeting } \\
\text { Designing and } \\
\text { exploiting the } \\
\text { scheduling systems } \\
\text { of production, } \\
\text { controlling } \\
\text { inventory and better } \\
\text { logistics to } \\
\text { minimize delivering } \\
\text { time and reducing } \\
\text { the times that the } \\
\text { required product of } \\
\text { customer that is not } \\
\text { available in the } \\
\text { stores or store of } \\
\text { their inventory }\end{array}$ \\
\hline Promotion & $\begin{array}{l}\text { Wide advertisements } \\
\text { with emphasis on the } \\
\text { superiority of } \\
\text { company's product }\end{array}$ & $\begin{array}{l}\text { Wide advertisements } \\
\text { with emphasis on the } \\
\text { superiority of } \\
\text { company's product } \\
\text { Promotion of sale in } \\
\text { order to encourage } \\
\text { customers to test the } \\
\text { product of company } \\
\text { or to change their } \\
\text { desire brand }\end{array}$ & $\begin{array}{l}\text { Advertising policy to } \\
\text { create consciously } \\
\text { and selective demand }\end{array}$ & $\begin{array}{l}\frac{\text { Wide }}{\text { advertisements }} \\
\underline{\text { aiming to make }} \\
\text { potential } \\
\text { customers aware }\end{array}$ & $\begin{array}{l}\text { Local, sudden, wide } \\
\text { but temporary } \\
\text { advertisements } \\
\text { Using promotional } \\
\text { activities of sale } \\
\text { such as selling } \\
\text { discount coupons } \\
\text { Legal claims against } \\
\text { the pioneered } \\
\text { company }\end{array}$ \\
\hline
\end{tabular}

Today's companies won't be able to survive without communicating with customers and knowing their opinions and attitudes towards the company performance. Companies should get the necessary knowledge regarding the determination and division of a market and also the products and services that provide the needs of different parts of the market; these factors have been chosen as objectives. They also should know different types of pricing methods in order to offer attractive prices. And by choosing the right distribution channels, they should 
try to put their products at the disposal of their customers. Carrying out advertising and product advancement (so that customers get the necessary information about these products and request them) are other domains companies should be aware of, and all the aforementioned factors means choosing a proper marketing mix. In the present study according to the strategic reference points and the respondents' viewpoints in this stage of company's life, the marketing strategy is attack from surrounding or blockade agreed by the managers and experts of the Kavir Lacquered Wire of Yazd Company. The requirement of taking attack from surrounding strategy is to perform marketing mix that includes the following cases:

- Product: Producing product with more attractive features for the customers whose requirements are not met

- Price: Choosing more attractive price than competitor's price for the customer

- Distribution: Creating distribution channels for accessing intact sections of market

- Promotion: Trying to increase customers' awareness of company's products

Moreover, if the blockade strategy is taken, the marketing mix should be performed as follows:

- Product: Creating diversity in the company's products based on the requirement of various sections of market

- Pricing: Determining price proportionate with the customers' requirement in various sections of market

- Distribution: Trying to distribute product in small sections of market with specific requirements

- Promotion: Wide advertisements with the aim of making potential customers aware of company's products

However, the current emphasis of the managers and experts of company are the following cases in the current marketing mix:

- Product: Creating minor changes in the company's existing products (guerrilla attack strategy)

- Pricing: Determining competitive price (long jumps strategy)

- Distribution: Adequate distribution of product and supporting and encouraging distribution mediators (long jumps strategy)

- Promotion: Trying to increase customers' awareness of the company's products (attack from surrounding strategy)

Therefore, about the fit of marketing strategy with marketing mix of company, it can be argued that according to the answers given, the required fit has not been obtained in this respect in three components of marketing mix, and only in the area of promotion, a fit can be observed between marketing mix and marketing strategy. An asymmetry between the strategies and marketing mix creates difficulties for the studied company to gain competitive advantage and in this situation, it would thus not be possible to expect business growth and advancement. Therefore, carrying out the following reforms and modification are recommended in order to create the symmetry in gaining competitive advantages. 
With regard to the findings, the directors and decision makers of this company are suggested to have a special look at their marketing mix components, and take step in the path of realizing the fit between marketing mix and marketing strategy of company by competent planning in the current stage of its lifecycle.

In the highly competitive global markets, the need of companies to create a unique and unbeatable identity, that is distinguishing themselves from the competitors, has become vital importance more than ever. A product in a modern marketing concept offers a value to the consumer. The consumption consumers and industrial consumers should have appropriate strategy in marketing area to success in the business markets and consequently they should compile appropriate marketing mix to make the objective operational.

Taken from the results of present research and from the experts' viewpoint, unfortunately, the fit only exists in the promotion area of marketing mix, and other elements are disproportionate with marketing strategy of company. Thus, the managers of company are suggested to take step in the path of logical changes in the elements of product, price, and distribution, and be steadfast in the path of strengthening the element of promotion.

Compiling strategic plan of marketing, and identifying the target customers, and their demands and tastes along with acquiring necessary information about the competitors and their weak and strong points, can provide the possibility of designing appropriate features in the services and products of company and also intelligent pricing policy. Through a comprehensive advertisement program, the possibility of introducing innovation in offering distinguished services compared with other companies through catalogue and brochure, attending at business exhibitions, mass media and the facilities of environmental advertisements are provided. These can help the realization of managers' goals of this company in acquiring competitive advantage in the format of marketing and brand management component.

In all above cases, considering this point is essential that the promotion programs require continuity and tracking. A successful activity cannot be known that much effective and prosperous without continuity, particularly, when the intensity of competition has increased and the customers due to the information bombardment usually make themselves away from the access of advertisers. Effective promotion usually needs substantial costs, but considering the competitive ability of company and its managerial support in Iran, the best use can be made of this capital and achieve competitive goals by more effectiveness in the form of an appropriate marketing strategy.

\section{References}

Adizes, I. (1989). Corporate life cycle: How and why corporations grow and die and what do about it. Englewood Cliffs, NJ: Prentice Hall.

Aharony, J., Falk, H, \& Yehuda, N. (2006). Corporate life cycle and the value relevance of cash flow versus accrual financial information. Working Paper, 34, school of economics and management Bolzano, Italy.

Aaker, D. A. (1991). Managing brand equity. New York: The Free Press.

Aliahmadi, A., Fathollah, M., \& Tajoldin, A. (2003). A comprehensive outlook on strategic management, 6th ed. Tehran: Publication of Tolid Danesh.

Anthony, J., \& Ramesh, K. (1992). Association between accounting performance measures and stock prices: A test of the life cycle hypothesis. Journal of Accounting and Economics, 15, 203-227. 
Arabi, S. M., \& Rezvani, H. R. (2007). The relationship between business and marketing strategies fit and organizational performance: A study in Tamin pharmaceutical investment co. Iranian Journal of Management Sciences, 2(5), 71-97.

Bateson, J. E. G., \& Hoffman, K. D. (1999). Managing services marketing, 4th ed. London: The Dryden Press, Harcourt Brace College Publishers.

Bulan, L., \& Yan, Z. (2010). Firm maturity and pecking order theory. Retrieved from www.ssrn.com/abstract $=1760505$.

Chandler, A., D. (1962). Strategy and structure. Massachusetts: The M. I. T. Press.

Ghasemi, H., Taghavi, M., \& Fani, M. R. (2006). Identifying and evaluating factors impacting on alloy steel industry marketing in Iran. Journal of Marketing Management, 1(1), 51-60.

Gheytarani, F. (2011). Choosing pomegranate marketing mix for export by using AHP method (case study: Pomegranate of Saveh) (Unpublished master's thesis). Executive Management, Marketing Orientation, University of Isfahan.

Gohar, G. S. (2010). Firm life cycle and the choice of the form of payout. Retrieved from https://ssrn.com/abstract=1632834 or http://dx.doi.org/10.2139/ssrn.1632834

Goharian, A. (2010). Determining appropriate marketing mix for export products from the viewpoint of consumers in the Persian Gulf region countries (Case Study: The Company of GazSekeh Isfahan) (Unpublished master's thesis). Business Management, Marketing Orientation, University of Isfahan.

Huang, R., \& Sarigöllü, E. (2012). How brand awareness relates to market outcome, brand equity, and the marketing mix. Journal of Business Research, 65, 92-99.

Jafarnejad, A., \& Mokhtarzadeh, N. (2007). The presentation of a quantitative model for auditing the conformity of production and marketing strategies. Iranian Journal of Management Sciences, 2(6), 95-122.

Jenkins, D. S., Kane, G. D., \& Velury, U. (2004). The impact of the corporate life-cycle on the value relevance of disaggregated earnings components. Review of Accounting and Finance, 3, 5-20.

Kallunki, J., \& Silvola, H. (2008). The effect of organizational life cycle stage on the use of Activity-based Costing. Management Accounting Research, 19, 62-79.

Katler, P. H., \& Armstrong, G. (2004). Marketing principles (B. Forozandeh, Trans.). Isfahan: Publication of Atropat.

Ketabi, S., Ansari, M. I., \& NaseriTaheri, M. (2005). Choosing appropriate marketing mix by using AHP technique with the approach of strategic planning of marketing. Journal of the Faculty of Administrative Sciences and Economics, 17, 79-92.

Kim, J., \& Hyum, Y. (2010). A model to investigate the influence of marketing-mix efforts and corporate image on brand equity in the IT software sector. Industrial marketing management, 40, 424-438.

MasoumzadehZavareh, A., \& Nasehifar, V. (2010). Auditing industrial marketing: Case Study, part making companies complex of Bahman group. Journal of Business Management, 4, 145-164.

Osta, S., \& Gheytasi, R. (2012). The impact of business unit lifecycle on discretionary accruals. Journal of Financial Accounting Researches, 4(1), 89-104.

Rezaie, F., \& Samani, K. (2014). The impact of lifecycle and size on the priority of external organizational financing options. Journal of Financial Accounting Researches, 6(2), 95-114.

Shafiei, M. (2012). Application of identifying the lifetime of organization in choosing technology acquisition strategies. Professional Quarterly of Parks and Growth Centers, 30, 22-31.

Talebzadeh, S. (2010). Identifying and ranking the most important marketing mix elements in purchasing tile and investigating three brands of Khzar, Tabriz, and Saman based on the identified elements (Unpublished master's thesis). Business Management, Islamic Azad University, Kermanshah Unit.

Villarejo-Ramos, A. F., \& Sanchez-Franco, M. J. (2005). The impact of marketing communication and price promotion on brand equity. Journal of Brand Management, 12(6), 431-444.

Walker, W., Harremoës, P., Rotmans, J., Van der Sluijs, J., Van Asselt, M. B. A., Jansen P., \& Krayer von Krauss, M. P (2003). Defining uncertainty: a conceptual basis for uncertainty management in model-based decision support. Journal of Integrated Assessment, 4(1), 5-17

Yoo, B., Donthu, N., \& Lee, S. (2000). An examination of selected marketing mix elements and brand equity. Journal of the Academy of Marketing Science, 28(2), 195-211. 